\title{
Abbreviations and Notes
}

\section{Abbreviations of work by Hugh MacDiarmid}

CP1 Complete Poems: Volume I, ed. Michael Grieve and W. R. Aitken (Manchester: Carcanet, [1978] 1993).

CP2 Complete Poems: Volume II, ed. Michael Grieve and W. R. Aitken (Manchester: Carcanet, [1978] 1994).

CSS Contemporary Scottish Studies, ed. Alan Riach (Manchester: Carcanet, [1926] 1995).

L The Letters of Hugh MacDiarmid, ed. Alan Bold (London: Hamish Hamilton, 1984; Athens, GA: University of Georgia Press, 1984).

LP Lucky Poet: A Self-Study in Literature and Political Ideas, Being the Autobiography of Hugh MacDiarmid (Christopher Murray Grieve), ed. Alan Riach (Manchester: Carcanet, [1943] 1994).

NSL New Selected Letters, ed. Dorian Grieve, Owen Dudley Edwards and Alan Riach (Manchester: Carcanet, 2001).

RT1 The Raucle Tongue: Hitherto Uncollected Prose, Volume I: 1911-1926, ed. Angus Calder, Glen Murray and Alan Riach (Manchester: Carcanet, 1996).

RT2 The Raucle Tongue: Hitherto Uncollected Prose, Volume II: 1927-1936, ed. Angus Calder, Glen Murray and Alan Riach (Manchester: Carcanet, 1997).

RT3 The Raucle Tongue: Hitherto Uncollected Prose, Volume III: 1937-1978, ed. Angus Calder, Glen Murray and Alan Riach (Manchester: Carcanet, 1998).

SE Scottish Eccentrics, ed. Alan Riach (Manchester: Carcanet, [1936] 1993).

SP Selected Prose, ed. Alan Riach (Manchester: Carcanet, 1992). 


\section{Notes}

Line references for A Drunk Man Looks at the Thistle have been appended to the CP1 page references (not given in the published CP1 text) to help readers situate citations in the long narrative of the Drunk Man's journey, and as an aid to readers using an edition of the poem other than that in CP1.

For clarity throughout this collection of essays, and except where otherwise stated, Grieve (and his numerous pseudonyms) has been standardised to MacDiarmid.

The volume editors would like to thank Carcanet Press Ltd and the MacDiarmid Estate for their kind permission to quote from the Carcanet MacDiarmid 2000 series. 